\title{
INVESTIGATION ON THE EXPERT COMMUNITIES AWARENESS OF THE URBAN RIVER WATER QUALITY, CASE STUDY OF SUGUTAMU RIVER, INDONESIA
}

\author{
Imas Komariah $^{1}$, Toru Matsumoto ${ }^{2}$ \\ ${ }^{1,2}$ Department of Life and Environment Engineering, the University of Kitakyushu \\ Kitakyushu, Japan \\ 1'imaskomariah95@gmail.com \\ ${ }^{2}$ matsumoto-t@kitakyu-u.ac.jp
}

\begin{abstract}
Many rivers in urban areas in Indonesia are commonly used as raw water sources for drinking water purposes. Therefore, the water quality of the rivers needs to be maintained. River restoration program becomes a major priority in improving the water sector and environmental, particularly in big cities in Indonesia. Sugutamu River is one of the main rivers passing through the Depok City, West Province of Indonesia. High population density has resulted in a critical land usage and water resources in many developing countries including in Indonesia. It will lead to the water quality deterioration. Stakeholder participations should be considered when implementing a participatory program in river restoration project. This program can be developed by increasing the awareness of the community. One of the most important communities is the 'expert' communities. In this research, economists, environmental specialists, river engineers, urban planners are selected as the 'expert' community. Questionnaires were distributed to the expert communities to investigate how the respondents concern about the importance of river water quality. The result shows that the awareness of the expert communityon river water quality and its improvement is higher than on other aspects.
\end{abstract}

\section{Keywords: expert community, Sugutamu River, urban river, water quality.}

\section{Introduction}

Urban river is defined as a stream where a significant part of the contributing catchment consists of development where the combined area of roofs, roads and paved surfaces results in an impervious surface area characterizing greater than $10 \%$ of the catchment [1]. Many rivers located in the urban area are functioned as the raw water source for the drinking water purposes. Therefore, the water quality of the rivers needs to be maintained. Unfortunately, rivers in urban areas are experiencing severe pollution due to activities that take place in the catchment area of the river. The source of pollution is notonly from the riverbanks, but also from activities in the basin that discharge their wastewater into the river.
Many kinds of efforts have been conducted to recover the river water quality in Indonesia [2].The efforts were conducted by government and community. The community living close to the river also carried out events to clean up the water, the government built some facilities to improve the water quality in several places [2]. River restoration program becomes a major priority in improving the water sector and environmental in Indonesia, especially in big cities. The program has been regulated by the Indonesian Government since 2011. Restoration programs have resulted in positive effects even in the small restoration projects. Nevertheless, the project outcomes did not positively increase with a bigger project size. No "single best" measure could be identified from the restoration projects, but river widening generally has a larger effect compared to other restoration measures [3]. 
Depok is a city located closed to Jakarta City. It plays an important role as a supporting area for the capital city of Indonesia, especially in providing residential areas for people working in Jakarta. Sugutamu River is one of the main rivers passing through the Depok. High population density has resulted in a critical land usage in many developing countries including in Indonesia. Many people use Sugutamu riverbank illegally as their residential area. This area is not supported by proper infrastructures, including waste management facility. Domestic and non-domestic activities in this area generate solid waste and wastewater which are discharged directly into the river without any prior treatment.

Sugutamu River is a tributary of the Ciliwung River. The main part of this river is located in the administrative area of Depok. The upstream of this river is in the Cibinong District while the downstream is in the Sukamajaya District, Bogor. Sugutamu River has a watershed elongated shape and functions as the primary channel to drain the runoff from the upstream area.

Based on the government activity in water quality monitoring, the river water quality profile of the upstream part was $6.71 \mathrm{pH}$, $15.67 \mathrm{mg} / \mathrm{L}$ TSS, $3.14 \mathrm{mg} / \mathrm{L}$ of dissolved oxygen (DO), $32.97 \mathrm{mg} / \mathrm{L}$ of biochemical oxygen demand (BOD), and $186 \mathrm{mg} / \mathrm{L}$ chemical oxygen demand (COD). Additionally, river water quality profile of downstream part was $6.78 \mathrm{pH}, 15.33 \mathrm{mg} / \mathrm{L}$ TSS, $1.56 \mathrm{mg} / \mathrm{L}$ DO, $19.63 \mathrm{mg} / \mathrm{L}$ BOD, and $124.27 \mathrm{mg} / \mathrm{L}$ COD [4]. Based on the aforementioned water quality data, the water quality of Sugutamu River has exceeded the government regulation's stream standard, especially for the BOD and COD concentrations. Therefore, Sugutamu River needs a significant improvement to restore the water quality conditions.

Urban stream rehabilitation decisions are usually dominated by conflicting triple bottom line pressures of social (including political), economic and environmental factors [1]. The rehabilitation effort has to be under the scope of an integrated water resources management. To strengthen water resources management, the capacity building is important. It will generate and analyze data, develop sustainable water management plans, use conflict resolution techniques, or encourage stakeholders' participation, and religious groups [5]. Stakeholders of the river management come from various institutions and communities, not only from government, but also from private sectors, researchers, people communities, and environmentalists [2].

River restoration program contains many aspects to be considered. The most important part of the program is water quality conditions. The interaction between teams preparing syntheses and expert entrepreneurs helps influence the construction of strategic policy narratives. Those narratives increase the impact of scientific evidence by communicating and framing key policy-salient messages, and brokering between broad ecosystem-based and environmental economics narratives [6].

When implementing a participatory program, stakeholder participation should be considered right from the outset, from concept development and planning, through implementation, to monitoring and evaluation of outcomes [7]. River restoration program might generate various problems. The complex and dynamic nature of environmental problems require flexible and transparent decision-making that embraces a diversity of knowledge and values [7]. In this research, the awareness of expert community on river water quality was investigated. When the expert community awareness is significantly high, river water pollution measurement can be applied directly in the pollutant source, therefore the river water quality treatment can be less intense. In the contrary, if the expert community awareness is low, the first effort to improve the river water quality is complete treatment facilities that require high budget preparation. 


\section{Methodology}

Prior to the main research, questionnaires were distributed to 100 people living near Sugutamu River was conducted to investigate community activities and events involving the river, i.e.:

- Benefits obtained from the river,

- Water usage of the river,

- recreational use of the river,

- river flood experience,

- Benefits the river restoration program, and

- Community interest in the river restoration.

Observation on the community is very important, mainly to formulate the most appropriate measures to improve the river condition. River pollution is mainly due to the lack of management for both liquid and solid wastes and lack of community participation in river management [8].

Data for this research was acquired mainly derive from the questionnaire results. Expert communities were defined in 4 categories, i.e.:

- Economists,

- Environmental experts,

- River engineers, and

- Urban planners.

Total number of respondents are 38 (thirty eight). In this research, expert communities are defined as a group or individual who can affect or being affected by the water quality of the river.

In order to find out the awareness of the community, the questionnaire is designed to understand the specific improvement priority sequence among 5 criteria, i.e.:

- River Water, which considers water quality, water quantity, water use, and water usage;

- Habitat, which considers biodiversity, aquatic species, biota population, terrestrial species;

- Cost, which considers financial need for river construction, routine maintenance, recreation facility development, wastewater treatment plant (construction and operation);

- Land use, which considers residential area, crop/plantation, industrial area, recreation places, and

- Action, which considers activities in community education, law and regulation enforcement, sanction and penalty, improvement of river construction.

Further investigation was taken place to discover the importance sequence among 4 aspects, i.e.:

1. Water quality

Includes all variables influencing the life of river's biota, such as color, turbidity, temperature, dissolved oxygen concentration, $\mathrm{pH}$, ammonia, and alkalinity.

2. Water quantity

Includes the amount of water exist in the river.

3. Water use

Water use means the type of area using the water from the river, such as residential, irrigation, and industry.

4. Water usage

Usage of water represents the type of activities using the water from the river, such as raw water for drinking water purposes or power plant.

Data gained from the questionnaire was analyzed to obtain the percentage of each expert community in prioritizing the criteria and aspects. This result will demonstrate the awareness of the expert community on the river water quality and put it as the top priority in river restoration.

\section{Result and Discussion}

Sugutamu River is positioned at $06^{\circ} 22^{\prime} 30^{\prime \prime}$ South Latitude, 106 $50^{\prime} 20^{\prime \prime}$ East Longitude, 06 $28^{\circ} 35^{\prime}$ " South Latitude, and $106^{\circ} 50^{\prime} 50^{\prime \prime}$ East Longitude. The total area of Sugutamu River catchment is $13.21 \mathrm{~km}^{2}$, with $13.74 \mathrm{~km}$ length. Figure 1 shows the map of Sugutamu River. 


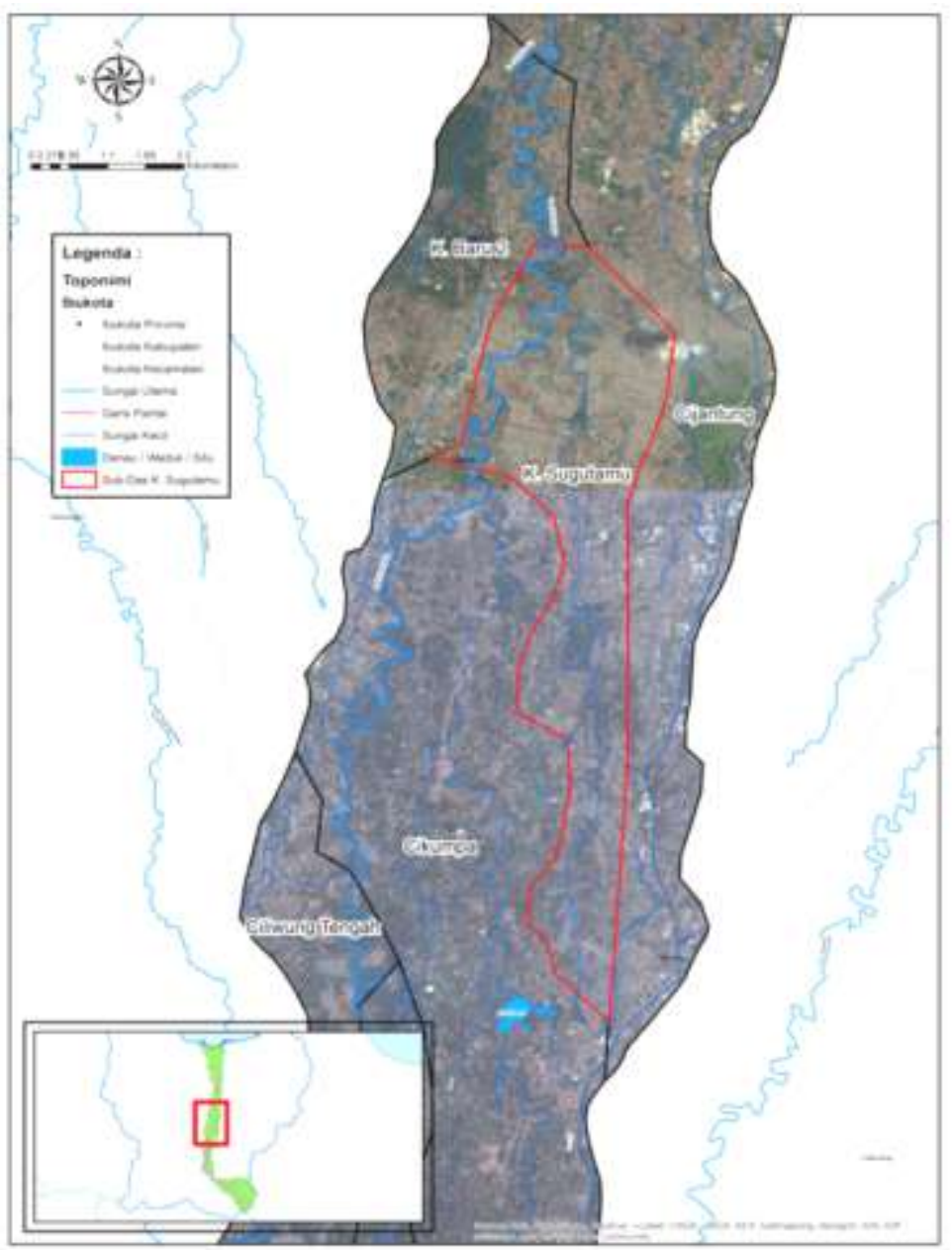

Figure 1. Map of Sugutamu Watershed

In the interview activity, some findings on surrounding community were obtained. Almost all of the communities (94\%) realize the important role of the river. Nevertheless, not many (32\%) of them use the water for daily purposes. Figure 2 shows the percentage of people who are living near the Sugutamu River and use the water for different purposes. It shows that the percentage of community using the water as 'often', 'occasionally', and 'never' is fairly the same. Figure 3 shows the utilization of Sugutamu River by the surrounding people. The people mostly use the river as the recreation area which might not need the high standard of water quality.

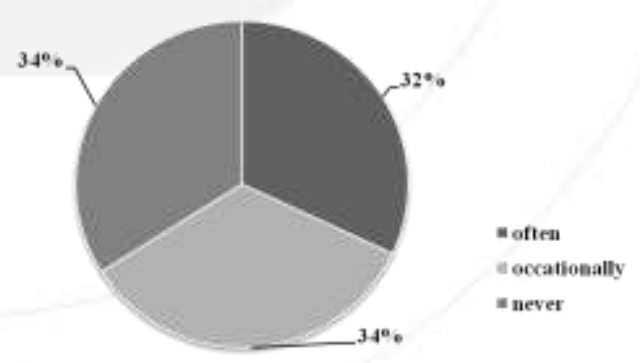

Figure 2. Utilization of Sugutamu River by the surrounding community 


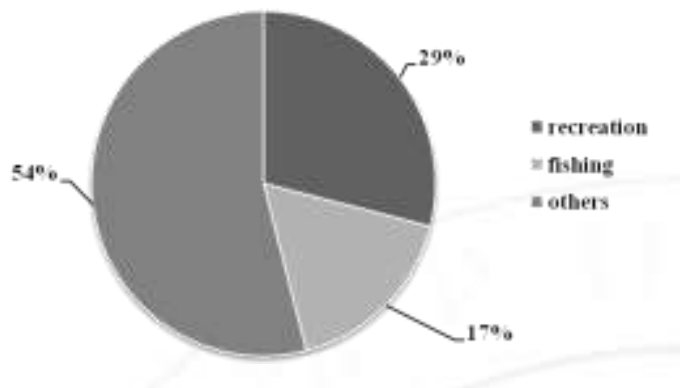

Figure 3. Type of utilization of Sugutamu

River by the surrounding community

About $42 \%$ of the community experienced the flood caused by the overflowing of the Sugutamu River. Sugutamu river often spills over during the wet season and causes flooding in the surrounding region [9].

The respondents mostly showed their interest in participating to support the activity of the river restoration program. About $48 \%$ of the respondents will participate directly to the program, 50\% will participate when they are being asked, and $2 \%$ will not participate in the program.

Figure 4 shows that three expert communities, i.e. economists, environmental experts and river engineers mainly considered the river water improvement as their first priority in river restoration. Criteria being considered are river water, habitat, cost, landuse, and action.

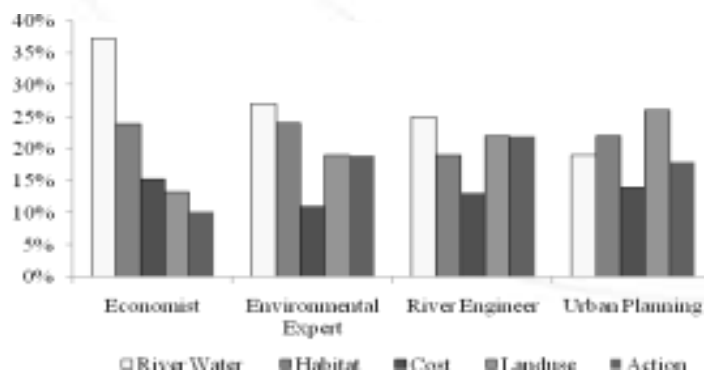

Figure 4. Percentage of each expert community to prioritize each criterion of the river

The urban planner community ranked the land use re-management and improvement as the first priority. This community considered the river water in the third priority after habitat rehabilitation.

All expert communities considered the cost category in the last priority. It shows that river construction, routine maintenance, recreation facility development, wastewater treatment plant construction and operation that need high budget can be considered after river water, habitat, and action categories.

Overall data shows that the first priority ranked by all of the communities is the river water. Habitat category was ranked as the second concern. It can be indicated in Fig. 5 the cost category was ranked as the lowest priority.

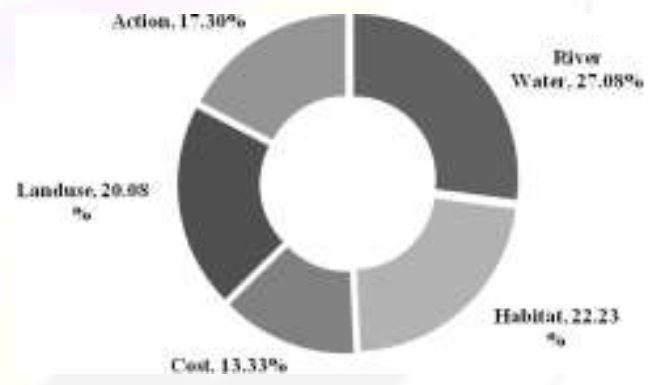

Figure 5. Percentage of each category for total respondents from all expert communities

Overall, the results show that the expert community is aware on the importance of river water. The highest percentage of the river water category was found in the economist community. It implies that this community is the most aware group on the river water improvement.

Figure 6 shows the percentage of each community to prioritize each aspect of the river. It demonstrates that three expert communities (i.e. economists, environmental expert and river engineers) identified the water quality as the first priority in improving the river water condition. The urban planners community ranked the water use improvement as the main concern. They prioritize the land use management as their first 
priority. This result is in line with the prioritizing category result, where the urban planners community concerned the land use as the first priority. The water quality was put in the last priority by the community in the river water sub-category after other aspects, i.e. water usage and water quantity.

Figure 6 also shows that the first three expert communities agree to ranked the water quantity, water use, and water usage as the second, third, and forth priority respectively.

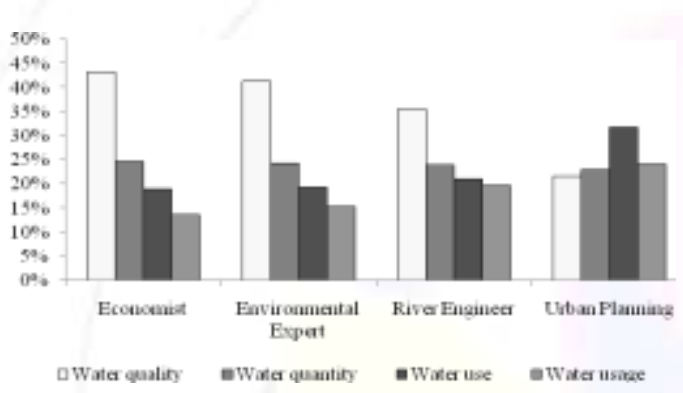

Figure 6. Percentage of each community to prioritize each aspect of the river

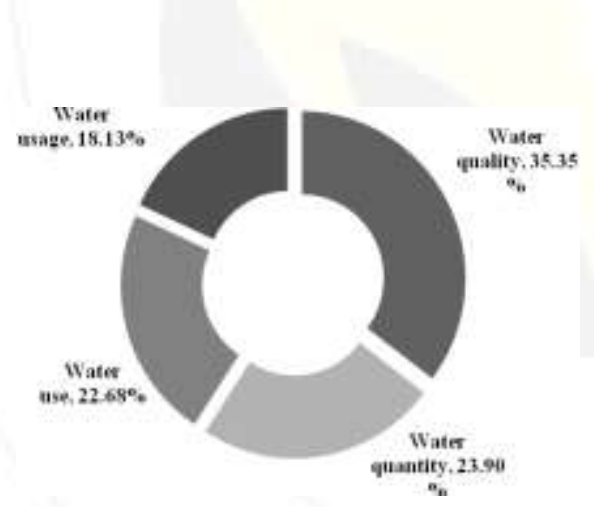

Figure 7. Percentage of each aspect for total respondents from all expert communities.

In total, $35 \%$ of all the expert communities ranked the water quality improvement as the first priority for the river restoration project. The water usage improvement is considered to be the lowest priority. The water quantity and water use were ranked as the second and third priority, respectively.

The result of the prioritizing aspect shows that awareness of the expert communities is significantly high on the water quality improvement. The most aware community for the water quality aspect was the economists.

High awareness of the expert community will simplify the process of the river restoration project as it will direct to the participation of the communities to the project. Participation should be considered as early as possible and throughout the process, representing relevant stakeholders systematically [7].

The increase of expert community awareness will stimulate the non-expert community awareness. However, there is little evidence to support claims that stakeholder participation in the environmental decision-making can promote or enhance social learning [7].

\section{Conclusion}

Most people in the people living near the Sugutamu River realize the important role of the river. Due to the water quality issues, not many people in the community use the water for daily purposes.

The expert community is aware on the importance of river water condition. The highest percentage of the river water category was shown in the economist community. This study shows that the economist community is the most aware expert on the river water improvement. Awareness of the expert community is also significantly high on the water quality improvement. The economist is also the most aware community on the water quality aspect.

The high awareness of the expert community will simplify the river restoration project, especially in the river water quality improvement. However, the involvement of either people (non-expert) or expert communities need to be designed effectively to have a success participatory process in river restoration.

\section{Acknowledgement}


A great appreciation is given to the BBWS (Balai Besar Wilayah Sungai/ Agency of River Region) Ciliwung-Cisadane in Indonesia that supported this research by providing some data.

\section{References}

[1] S.J. Findlay, M.P. Taylor, "Why rehabilitate urban river systems?", Area, 38.3, 2006, pp. 312-325

[2] Y.M. Yustiani, and L. Lidya, "Towards an Information System of Modeling and Monitoring of Cikapundung River, Bandung, Indonesia", Procedia Engineering 154, 2016, pp. 353-360, doi:10.1016/j.proeng.2016.07.490

[3] S. Muhar, K. Janusch, J. Kail, M. Poppe, S. Schmutz, D. Hering, A.D. Buijse, "Evaluating goodpractice cases for river restoration across Europe: context, methodological framework, selected results and recommendations",

Hydrobiologia, Vol. 769, 2016, pp. 3-19. doi:10.1007/s10750016-2652-7

[4] A. Nurhidayat, "Komposisi Timbulan Limbah Padat dan Kualitas Air Sungai Sugutamu pada Sub-DAS Sugutamu" (Composition of Solid Waste and Water Quality of Sugutamu River at Sugutamu Sub-Watershed), in Indonesian, http://lib.ui.ac.id/naskahringkas/2 015-09/S-Ade\%20Nurhidayat, accessed May, 2016.
[5] L.S- van der Kley, L. Reijerkerk, "Water a Way of Life, Sustainable Water Management in a Cultural Context", CRC Press. pp 107, 2009"

[6] E. N. Lawton, M.A. Rudd, "Scientific evidence, expert entrepreneurship, and ecosystem narratives in the UK Natural Environment White Paper", Environmental Science and Policy, Vol. 61, 2016, pp. 24-32

[7] M.S. Reed, "Stakeholder participation for environmental management: A literature review", Biological Conservation, 141, 2008, pp. 2417-2431, doi:10.1016/j.biocon.2008.07.014

[8] A Manan, M. Ibrahim, "Communitybased river management in Southeast Sulawesi, Indonesia: a case study of the Bau-Bau River" Water Sci Technol. Vol. 48(7) 2003 pp.181-90

[9] M. Nabilah, B. Santosa, “Analisis Kapasitas Drainase Primer pada SubDAS Sugutamu Depok (Capacity analisys of primary drainage of Sugutamu sub-Watershed)", in Indonesian, Prosiding PESAT (Psikologi, Ekonomi, Sastra, Arsitektur, dan Teknik Sipil), Vol. 6, 2015, pp.T-55-T-61

\section{Imas Komariah}

The first author is a doctoral student at the University of Kitakyushu, Japan. She works for the Indonesian Government in the sector of Agrarian and Spatial Planning. Her main interest is in the environmental management area.

Toru Matsumoto

The second author is a full professor at the University of Kitakyushu, Japan. 